\title{
Realismo Cognitivo, Naturalismo e Pragmatismo Ético: a Estrutura Normativa das "Formas DE VidA" SEgundo Habermas e Putnam
}

\author{
ERICK LIMA
}

\begin{abstract}
The paper aims at recovering some epistemological issues in the debate between Putnam and Habermas about the objectivity of values. To begin with, I take up some discussions in philosophy of language and pragmatism in order to develop a framework according to which it is possible a less unilateral comprehension of the relation between naturalism and the normativity of 'life forms' (1). This account attempts to contextualize the Habermas/Putnam debate. Then I summarize Putnamt's positions (2). Thirdly, after pointing out what appears to be the common argumentative position by delineating the boundaries of ethical pragmatism, the paper focuses on its meaning for contemporary issues in practical philosophy (3). Finally, I argue that Habermas is successful at responding to Putnam's critics, although he thereby adheres in his account of deontological morality to an axiological orientation based on vulnerability (4).
\end{abstract}

Keywords: Pragmatism; realism; naturalism; normativity; Habermas; Putnam.

Nas últimas décadas, na esteira do diagnóstico feito por Rawls acerca do caráter inexoravelmente constitutivo que assume o pluralismo valorativo nas sociedades democráticas, ${ }^{1}$ Hilary Putnam e Jürgen Habermas se engajaram numa controvérsia sobre um dos temas mais importantes e decisivos na filosofia política, a saber: o sentido cognitivo dos enunciados valorativos em face das pretensões normativas de validade e também, em última instância, frente à reivindicação de validade objetiva do conhecimento acerca dos fatos. Ponto central do debate entre os dois filósofos é, portanto, se e como, diante do "fato do pluralismo" como realidade política inescapável da modernidade, de sua forte herança kantiana e da aposta teórica num realismo cognitivo alheio às consequências eventualmente relativistas do contextualismo, pode-se trabalhar, para além das dimensões enfáticas de validade cognitiva e normativa, com uma objetividade enfática no âmbito prático-cultural dos valores.

Pluralismo axiológico é a manifestação, em termos do potencial conflito entre orientações práticas possíveis, do fato aferível por via empírica e sociológica da perda pela modernidade da aceitação pública de uma imagem única e de uma hierarquia objetiva capaz de determinar as ações. Uma teoria da normatividade tem de corresponder ao desiderato de estabilizar o pluralismo, mantendo, de preferência, uma visada "pragmatista" com expectativas falibilistas e anticéticas.

Principia 17(3): 459-488 (2013).

Published by NEL — Epistemology and Logic Research Group, Federal University of Santa Catarina (UFSC), Brazil. 


\section{Realismo Cognitivo, Naturalismo e a Pragmática Normativa}

Habermas compreende Putnam como herdeiro da tradição kantiana, como um teórico que compartilha com ele próprio - juntamente com Apel e Peirce - o "pragmatismo kantiano" (Habermas 2004, p.16), apesar de entender que ele não adere à noção de autonomia como autolegislação, permanecendo, em termos de filosofia prática, ligado a um pragmatismo aristotélico (Habermas 2002b, p.80). Mesmo assim, do ponto de vista epistemológico, o "realismo interno" defendido por Putnam contra o realismo metafísico, o representacionalismo e a ideia da verdade como correspondência, inspira-se na filosofia transcendental de Kant e, mesmo sob condições pós-metafísicas de destranscendentalização do sujeito cognoscente, não sucumbe ao contextualismo ou ao naturalismo radical. Em suma, para Habermas, Putnam ilustra o feliz caso de uma proposta epistemológica, de um "transcendentalismo linguístico" (Habermas 2002b, p.84), que, apesar de aderir à ideia descoberta pela virada linguística de um acesso não mediado linguisticamente à realidade nua, por se vincular à "premissa realista básica", continua a se pautar tanto por uma compreensão falibilista do conhecimento e pelo caráter indefinido e potencialmente aberto do aprendizado, quanto por pretensões enfáticas de validade, sem sucumbir, por conseguinte, ao naturalismo radical, ao relativismo e ao contextualismo (Bernstein 2011, p.16878). As linguagens enquanto sistemas conceituais formam conjuntos de condições possibilitadoras, um meio no qual se estabelece intersubjetivamente o contato com o mundo e, também por isso, o incremento recíproco de nosso saber do mundo e dos sistemas conceituais.

Sob as condições de perda de plausibilidade da noção kantiana de "transcendental", a ideia de condições de possibilidade se converte, para Habermas e Putnam, na participação dos falantes e agentes em práticas e contextos de cooperação linguisticamente estruturados, nos quais, a despeito da interpretação linguística compartilhada do mundo, seu embate específico e falível com a realidade contingente suscita processos de revisão dos contextos linguísticos. Habermas se entende compartilhando a visada teórica de Putnam na medida em que, contra Quine, Rorty ou Brandom, embora se trate para todos de uma "destranscendentalização" da racionalidade — incrustada agora em comunidades linguísticas históricas — nem por isso se possa falar de nivelamento do mundo da vida e da objetividade. Apesar da destranscendentalização, Habermas continua apostando, na suposta companhia de Putnam, na diferenciação entre o sensível e o inteligível, isto é, na possível preservação de uma perspectiva objetivante, observadora, distanciada do horizonte compartilhado das práticas comuns, a partir da qual, submetido o "a priori cultural de sentido" (Habermas 2004, p.82) ${ }^{2}$ à perda da "imediatitade", o acesso ao conhecimento intuitivo dos indivíduos em linguagens gramaticais e em formas de vida normativas perde sua supremacia em favor de discursos de pretensão de validade.

Principia 17(3): 459-488 (2013). 
Tais circunstâncias teóricas vinculadas à destranscendentalização conduzem o pragmatismo kantiano, defende Habermas, à defesa do uso da primeira pessoa do plural às comunidades concretas de justificação, tanto no plano científico de seleção de teorias quanto no registro das práticas cotidianas nas quais se dá o intercâmbio cultural. Eis por que o transcendentalismo linguístico é também um universalismo reflexivo (Habermas 2002b, p.87). ${ }^{3}$

\section{Habermas: pragmatismo e naturalismo}

A elucidação da compatibilidade entre a investigação da "normatividade das formas de vida", isto é, uma investigação das "formas de vida" que toma como fio condutor as normas conceituais que estruturam a vida social compartilhada, e uma perspectiva epistemológica naturalista e realista, pode ser obtida pela visualização da forma como Habermas entende o impacto da pragmática linguística, da hermenêutica e do pragmatismo sobre a noção kantiana de experiência, ${ }^{4}$ em jogo na solução oferecida por Kant para os dilemas do empirismo moderno. Pelo "deflacionamento pragmático da conceitualidade kantiana" (Habermas 2004, p.18), a noção de transcendental se desconecta da noção mentalista de reflexão, e da dicotomia fundamentalista e ontológica entre a priori/a posteriori, passando a responder pela ideia de uma reconstrução ${ }^{5}$ das competências práticas e cognitivas em jogo no envolvimento dos falantes/agentes em práticas compartilhadas, seu envolvimento em comportamentos regidos por "regras" (Wittgenstein 1984, 1, p.345-6) pelas quais se estabelecem, como "proposições gramaticais" (Wittgenstein 1984, 1, p.353-438), validades objetivas, axiológicas e normativas. "Compreender é possuir as capacidades que se exercitam quando se usa a linguagem no uso da linguagem." (Putnam 2008, p.30) A reconstrução de capacidades prático-cognitivas de falantes/agentes, como aquela tencionada por Wittgenstein a respeito do conceito de compreensão (Wittgenstein 1984, 1, p.333-56), recoloca a distinção epistemológica entre o transcendental e o empírico, isto é, entre a compreensão "epistemológica” da normatividade conceitual das "formas de vida" e o "saber intuitivamente adquirido", "o saber implícito relativo às regras", os saberes de uso de caráter holístico que constituem o mundo da vida intersubjetivamente estruturado (Habermas 2004, p.19).

A "totalidade das práticas que se entrelaçam constituindo uma forma de vida torna-se relevante de um ponto de vista epistemológico" (Habermas 2004, p.21). Trata-se aqui, por conseguinte, de uma reformulação instigante do enfoque epistemológico das ciências humanas: ênfase é conferida à análise das estruturas corporificadas nas práticas socioculturais compartilhadas e nas posturas prático-cognitivas de falantes/agentes. Nessa constelação, assume papel epistemologicamente relevante a noção de "processo de aprendizagem" (Habermas 2004, p.19), ou seja, uma investigação do conhecimento a partir dos processos falíveis e não-lineares de formação das 
capacidades prático-cognitivas, no bojo do enfrentamento cooperativo, ilocucionário (Austin 1975, p.145-6), simbolicamente mediado, das frustrações impostas aos modelos explicativos pelos processos naturais, eles próprios não passíveis de acesso a não ser através de sua estruturação proposicional (Habermas 2004, p.20).

A esse entrecruzamento das dimensões epistêmicas e não-epistêmicas (Habermas 2004, p.21) se dirige a ênfase de uma investigação do conhecimento atrelada às atividades regidas por regras e normas conceituais, as quais governam, respectivamente, intervenções instrumentais e estratégicas, por um lado, e constituem o contexto simbólico da interação e das práticas comuns. Processos de aprendizagem são resultantes da contração da intersubjetividade compartilhada, ocasionada no "processamento cognitivo dos problemas que se põem no trato prático com o mundo." (Habermas 2004, p.24) Eis por que a problematização da obviedades acessadas intuitivamente através da prática argumentativa de justificação de pretensões de validade objetiva suscita a reconstrução da relação tensa entre a objetividade do mundo suposto como autônomo e idêntico para todos, acessível de forma observacional, e a "intersubjetividade do entendimento mútuo", acessível por participação e, a fortiori, compreendida e interpretada pela adoção de uma atitude performativa. ${ }^{6}$

A modificação imposta pelo pragmatismo na oposição entre o transcendental e o empírico fica por conta do fato de que os pressupostos contrafactuais, reivindicados na reconstrução do saber submetido a regras, estão inseridos na própria facticidade das práticas constitutivas do mundo da vida intersubjetivamente compartilhado. O verdadeiro sentido do movimento de "destranscendentalização", iniciado por Hegel (Habermas 2004, p.183), intimamente ligado à tese do "reconhecimento intersubjetivo"7 como tessitura do mundo da vida, consiste em fazer notar que o ponto de vista reconstrutivo se apoia, no que concerne às idealizações que lhe são necessárias, na socialização e formação de competências prático-cognitivas pelo envolvimento em práticas regradas; pois, de fato, sem aqueles elementos contrafactuais não se pode visualizar o grau mínimo de estabilidade de uma forma de vida: a reprodução "simbólica" e "material".

Eis como, a propósito, o pragmatismo pode se coadunar com o pressuposto realista de um mundo independente do espírito, a partir de cujas imposições se moldam pretensões de validade objetiva e processos de aprendizagem das capacidades práticas e cognitivas nelas envolvidas. As reivindicações idealistas, que provém de uma “concepção monológica de espírito" e conduzem, em geral, às aporias metafísicas e representacionalistas (Brandom 1994, p.93) a respeito da capacidade para acessar a realidade independente, são neutralizadas pela tese semântico-pragmática da constituição do mundo pelas proposições gramaticais, pela primazia da descrição sobre descrito (Wittgenstein 1984, 1, p.263-4). O "choque" entre o espírito e o mundo dos objetos, as inúmeras limitações dele resultantes, são tantas formas de constituição do mundo pela intersubjetividade situada, formas de experiência demandada pelos 
interesses, valores e posturas de uma "forma de vida", os quais se incorporam em tipos de comportamento atinente a regras. ${ }^{8}$

Cada um a seu modo, Habermas e Putnam retiram desse caráter constitutivo do mundo apresentado pelas diversas gramáticas consequências epistemológicas que excedem o contextualismo de uma "primazia do a priori do sentido" (Habermas 2004, p.82). Habermas procura evidenciar tanto o caráter da linguagem como medium estruturante em geral do mundo da vida, uma estrutura universalmente difundida das formas de vida sócio-culturais, como também o caráter "empiricamente universal" das

regras epistemicamente relevantes da atividade controlada pelo sucesso. São elas que, no curso da superação de situações problemáticas, abrem acesso ao mundo como totalidade de objetos que podem ser apreciados sob aspectos de possível manipulação ou disponibilização. (Habermas 2004, p.28).

Com efeito, o pragmatismo inspirado em Kant e na ideia wittgensteiniana da constituição do mundo pelas gramáticas estabelece certa relação também com a perspectiva naturalista, que atualmente se desenvolve a reboque das pesquisas biológicas, genéticas, evolucionistas e neurofisiológicas. Tal relação é marcada por certa possibilidade de compatibilização, a qual impõe, entretanto, limites à tendência teórica de naturalização da normatividade das formas de vida e das competências que habilitam falantes e agentes a participarem das práticas que constituem os comportamentos atinentes a regras. Aquilo que, da perspectiva dos participantes, requer um acesso hermenêutico pela via da compreensão - resultando, portanto, em última instância, na reconstrução das práticas intuitivamente dominadas e compartilhadas por falantes e agentes competentes — pode também, do ponto de vista da observação do encadeamento dos eventos na história natural, ser considerado na perspectiva da "gênese do equipamento do organismo humano e de suas competências específicas explicada em termos causais." (Habermas 2004, p.29) Trata-se com isso de assegurar a irredutibilidade completa do normativo ao natural. A perspectiva naturalista se baseia, em primeiro lugar, numa descrição dos sistemas de regras na qual se faz necessária elucidação conceitual das regras constitutivas de práticas, que definem, portanto, a própria forma de experiência e acesso ao mundo pelos falantes e agentes competentes. Em outras palavras, a adoção da perspectiva do observador requer abstração a partir da participação. ${ }^{9}$

A apropriação pelo pragmatismo da ideia de constituição transcendental da experiência, potencializada pela gramática wittgensteiniana dos jogos de linguagem, na medida mesmo em que permanece atrelada ao realismo cognitivo, delimita uma dimensão naturalista. Trata-se, no entanto, segundo Habermas, de um "naturalismo fraco" (Habermas 2004, p.31-38), refratário a uma compreensão puramente cienti- 
ficista dos elementos cognitivamente condicionantes, a uma redução do aparato cognitivo àquilo passível de ser descrito conforme procedimentos das ciências empíricas nomológicas. Tal "naturalismo forte", que Habermas percebe emblematicamente representado pelos continuadores de Quine, tende a fazer colapsar a distinção entre as condições práticas e socioculturais de constituição do mundo, sujeitas à análise conceitual, por um lado, e os eventos intramundanos passíveis de explicação causal e nomológica. Com esse nivelamento, ocorre uma "assimilação objetivista de nossas práticas normativas aos eventos observáveis do mundo" (Habermas 2004, p.32). Em última instância, tal estratégia teórica persegue o objetivo de reconduzir a autocompreensão de falantes/agentes competentes a uma compreensão estritamente naturalista de seu comportamento linguístico como resposta posterior ao processamento de estímulos sensoriais. ${ }^{10}$

Habermas pretende que o "naturalismo fraco" preserve a diferença transcendental entre o mundo, condicionado pelas práticas socioculturais, e os processos intramundanos, passíveis de explicação causal e nomológica. Com isso, o "naturalismo fraco" aciona necessariamente o "dualismo metodológico entre a reconstrução compreensiva de nosso mundo da vida e a explicação de processos em nosso mundo objetivo" (Habermas 2004, p.31), renunciando à intenção de compatibilizar terminantemente a visão participativa das regras constitutivas de práticas compartilhadas com a observação exteriorizada dos eventos mundanos. Ao separar estritamente a reconstrução racional e hermenêutica de estruturas do mundo da vida, pela via da participação nas práticas constituídas por regras, da "análise causal da gênese histórico-natural dessas estruturas" (Habermas 2004, p.36), o "naturalismo fraco", ao qual se filia o resgate do argumento transcendental pelo pragmatismo, debela a subordinação das práticas compartilhadas à primazia de uma atitude objetivante: "ele reúne, no nível metateórico, as duas perspectivas teóricas sempre mantidas separadas, na medida em que supõe a continuidade entre natureza e cultura." (Habermas 2004, p.37)

Tal como o faz Putnam em relação à gênese teórica de seu "realismo interno" (Putnam 2008, p.30), Habermas acusa o "representacionalismo" - estratégia epistemológica que, fixada numa estrutura dualista (enunciado/estado-de-coisas ou representação e objeto), "faz abstração da dinâmica do crescimento do saber pela solução de problemas e pela justificação" (Habermas 2004, p.34) — de negligenciar o ponto de vista pragmático sobre o processo cognitivo. A cognição do mundo tem sempre "por trás de si" o processo pelo qual o homo sapiens tem acumulado seu saber, "o trato inteligente com um mundo circundante cheio de riscos" (Habermas 2004, p.34), pela resolução de problemas axiológicos e técnicos, e possibilitando novos processos de aprendizagem. "Os juízos empíricos formam-se nos processos de aprendizagem e provêm de soluções de problemas." (Habermas 2004, p.35) Ao invés de representar a realidade, o homo sapiens conhece a realidade pela atuação da

Principia 17(3): 459-488 (2013). 
mesma nas (e sobre as) práticas compartilhadas, num atrito gerador de problemas para cuja solução a espécie se vale de processos aprimorados de aprendizado.

O processamento das resistências é algo que se realiza do ponto de vista perfomativo do participante em práticas intersubjetivamente válidas: "o conhecimento depende desses ingredientes [subjetivos] e mediações [intersubjetivas]" (Habermas 2004, p.35) Finalmente, na medida em supõe a continuidade entre natureza e cultura, evitando a pretensão reducionista do naturalismo estrito, ${ }^{11}$ tal modelo pragmático do conhecimento

apoia-se numa única suposição metateórica: a de que nossos processos de aprendizado - possíveis na moldura das formas de vida socioculturais de certo modo apenas dão continuidade aos "processos de aprendizado evolucionários" prévios, os quais, por seu turno, produziram as estruturas de nossas formas de vida. (Habermas 2004, p.6)

\section{Putnam: realismo e referência}

Não posso aqui, por razões óbvias, fazer uma análise pormenorizada da arguta e interessante intervenção proposta por Putnam no âmbito da epistemologia. É suficiente para os propósitos que persigo mais à frente compreender seu projeto no escopo mais geral, indicando o ponto em que tal programa filosófico se conecta com a questão epistemológica do realismo ${ }^{12}$ e com o significado mais geral do encaminhamento pragmático na "guinada linguística". Pretendo apenas mostrar o teor mais geral da posição epistemológica compartilhada por Putnam e Habermas, um "pragmatismo kantiano" (Habermas 2004, p.16), bem como o respaldo a tal classificação, alinhavado a partir das reflexões de Putnam sobre o problema da referência.

Sabe-se como intervenções mais recentes de Putnam - refiro-me, por exemplo, a The threefold Cord: mind, body and world - tratam de uma enfática defesa do "realismo direto (ou, como prefiro denominá-lo, o realismo natural)" diante da persistência de uma teoria da percepção proveniente de estratégias do pensamento moderno.

A epistemologia que acompanha essa perspectiva envolve na maioria das vezes uma teoria causal da percepção. De acordo com essa teoria, os objetos que apreendemos dão origem a séries de eventos que incluem o estímulo de nossos órgãos dos sentidos e, por fim, a presença de "dados dos sentidos" em nossa mente. Em versões materialistas da teoria, pressupõe-se que os "dados dos sentidos" sejam equivalentes a eventos físicos existentes em nosso cérebro; em variações recentes do tema materialista inspiradas na ciência cognitiva, afirma-se que esses eventos do nosso cérebro são um subconjunto das "representações mentais" ou os dados de "saída" de determinados "módulos" e assim por diante. (Putnam 2008, p.40)

Principia 17(3): 459-488 (2013). 
Putnam vê este paradigma como decorrente, principalmente, das opções teóricas conectadas à matematização da natureza; pois, na esteira da compreensão da natureza pela via da "lei matemática" (Putnam 2008, p.41), eventos conscientemente vivenciados "foram relegados à condição de meras afecções subjetivas da mente" (Putnam 2008, p.42). Com o pressuposto de uma descrição da natureza através do uso de fórmulas matemáticas, pensa Putnam, não se pode mais "afirmar que as descrições cotidianas das coisas possivelmente não se podem aplicar às coisas "tal como elas são em si mesmas"." (Putnam 2008, p.42) De fato, não se pode negar que a concepção moderna de cognição está atrelada, em todos os "teóricos da afecção", à tentativa de compatibilizar, através da enfática distinção interno/externo, "nossas descrições cotidianas" (Putnam 2008, p.42) e a "descrição da natureza mediante o uso de fórmulas matemáticas" (Putnam 2008, p.42), num movimento que tem como enunciação clássica a ideia de que "é possível conceder um tipo derivativo de realidade mesmo à cor, ao calor e às outras "qualidades secundárias", (como passam a ser chamadas): estas não existem como "propriedades intrínsecas" das coisas "em si mesmas", mas sim como "propriedades relacionais", como disposições que afetam nossa mente (ou nosso cérebro) de determinadas maneiras" (Putnam 2008, p.42). ${ }^{13}$

Para a percepção da relação entre o movimento teórico tencionado por Putnam e os desdobramentos pragmáticos ${ }^{14}$ da "guinada linguística", é digna de nota a maneira como tematiza a sustentabilidade do "realismo natural", da referência às coisas exteriores (Putnam 2008, p.43), a partir da forma como, por exemplo, Wittgenstein e Austin se posicionam frente à "refutação tradicional do "realismo ingênuo"." (Putnam 2008, p.43), aquele principalmente no "argumento da linguagem privada", ${ }^{15}$ este "no contexto de um ambicioso projeto de tentar convencer o mundo filosófico da importância de um estudo atento das maneiras pelas quais os conceitos são apresentados na linguagem ordinária" (Putnam 2008, p.44).

O argumento da linguagem privada em Wittgenstein (Wittgenstein 1984, 1, p.357 e seguintes) corrobora a tendência, presente na discussão sobre a "gramática das cores" dos "parágrafos sobre o Teeteto" (Wittgenstein 1984, 1, p.265 e seguintes), de submeter eventos vivenciados à estruturação pela normatividade conceitual da linguagem pública. O encaminhamento pragmático da "guinada linguística" assume para Putnam o caráter de uma discussão epistemológica sobre o "realismo interno".

A ideia de que nossas palavras e nossa vida são constrangidas por uma realidade exterior a nós desempenha um importante papel em nossa vida e deve ser respeitada. A fonte de confusão reside no erro filosófico vulgar de se supor que o termo realidade tem de referir-se a uma supercoisa, em vez de considerar as formas como renegociamos incessantemente - e somos forçados a renegociar — nossa noção de realidade à medida que nossa linguagem e nossa vida se desenvolvem. (Putnam 2008, p.23) ${ }^{16}$

Principia 17(3): 459-488 (2013). 
Putnam encontra numa "ingenuidade em relação ao significado" (Putnam 2008, p.19) o sintoma de uma posição filosófica que, ao refutar o "realismo tradicional" (Putnam 2008, p.19), questiona a independência do mundo. Os críticos do "realismo tradicional" se comprometem, segundo Putnam, com a tese de que na experiência ${ }^{17}$ "a forma de todas as alegações de conhecimento [e] os modos pelos quais elas são responsáveis perante a realidade são estabelecidos de antemão e de uma vez por todas, ao contrário dos pressupostos do realista tradicional." (Putnam 2008, p.20) Por outro lado, pensa Putnam, desde o pragmatismo de James dispõe-se da ideia de que "a "descrição" nunca é uma mera cópia e de que estamos sempre criando novas maneiras de a linguagem poder ser responsável perante a realidade." (Putnam 2008, p.22) $)^{18}$

A perspectiva alinhavada quase paralelamente por Wittgenstein e Austin é assimilada por Putnam numa defesa enfática do realismo natural, embora Putnam apresente a tendência de pensar a questão sobre a acoplagem de pensamento/linguagem e mundo como, em certo sentido, subsidiária da questão acerca da percepção (Putnam 2008, p.27). Para Putnam, há um entrelaçamento inextricável entre a defesa do realismo e a compreensão da relação entre linguagem e realidade. Na filosofia da percepção de extração cartesiana, as "entradas perceptivas" (Putnam 2008, p.32) fornecem ao processo cognitivo seu limite exterior. Ora, nesse sentido, pensa Putnam, "se o tipo de realismo que conhecemos desde o período moderno, incluindo a teoria causal da percepção, estiver correto, então tudo que acontece dentro da esfera da cognição deixa em geral a referência objetiva de nossos termos quase totalmente indeterminada." (Putnam 2008, p.32) Se, por um lado, com o realismo tradicional fica obstaculizada a própria noção linguisticamente articulada de uma pretensão de objetividade, por outro lado, tal paradigma consegue ainda menos fazer sentido da relação entre percepção e interpretação: "Um mundo que interpreta nossas palavras para nós, um mundo onde existem, vamos dizer, "raios noéticos" emitidos do exterior para a nossa cabeça ... é um mundo mágico, um mundo de fantasia." (Putnam 2008, p.32) A posição avançada por Putnam requer, do ponto de vista de sua trajetória intelectual, sobretudo o abandono da identificação do aspecto qualitativo das sensações como ocorrências físicas, na direção da ideia de que "as restrições operacionais da interpretação de nossa linguagem referem-se justamente a nossos dados dos sentidos." (Putnam 2008, p.36)

Habermas se conecta de maneira enfática a Putnam, sobretudo, na articulação entre o problema da linguagem e o "realismo sem representação" (Habermas 2004, p.38), isto é, a combinação entre a refutação — baseada na ideia de uma indissolúvel interpenetração de linguagem e realidade, da cognição "situada" em práticas do mundo da vida - da perspectiva mentalista de uma análise epistêmica em termos de "afecções de nossa subjetividade" (Putnam 2008, p.37), por um lado; e o "primado genético da natureza sobre a cultura" (Habermas 2004, p.39), perspectiva 
devedora de uma adesão do pragmatismo ao "naturalismo fraco". "Apenas o pressuposto, inerente a tal realismo, de um mundo objetivo intersubjetivamente acessível pode conciliar o primado epistêmico do horizonte do mundo da vida linguisticamente articulado, que não podemos transpor, com o primado ontológico de uma realidade independente da linguagem, que impõe limites às nossas práticas" (Habermas 2004, p.39).

O paralelo somente é aguçado quando se percebe a importância da teoria da referência desenvolvida por Putnam na maneira como Habermas concebe uma alternativa no quadro formado pela antinomia, ${ }^{19}$ decorrente do "primado da natureza sobre o espírito", entre o realismo conceitual, vinculado à estratégia de conceber o mundo em sua articulação proposicional, e o nominalismo, fundado na decisão teórica de conferir primazia aos "átomos" singulares como componentes do mundo (Habermas 2004, p.38-42). Se, por um lado, o realismo conceitual gramatical (2004, p.41) se mantém, enquanto herdeiro do entrelaçamento entre linguagem e realidade social, concebido na "atividade de seguir regras" (Wittgenstein 1984, 1, p.345), ligado à tese de uma existência dos objetos inseparável dos enunciados, corre sempre o risco de incorrer na hipóstase de uma constituição ontológica do mundo objetivo: a cognição de estados de coisa pré-estruturados proposicionalmente inviabiliza a ênfase sobre a "contribuição construtiva que sujeitos socializados, no trato inteligente com uma realidade arriscada e decepcionante, prestam a partir de seu mundo da vida, para chegar a soluções de problemas e processos de aprendizagem bem-sucedidos." (Habermas 2004, p.41) A reação conceitual-realista à ontologia atomista traz assim a inconveniente neutralização da componente falibilista associada ao realismo cognitivo. "Apenas a contribuição construtiva de nossas operações para o saber explica por que a ampliação do saber deve passar pela eclusa da revisão permanente do saber existente e por que um saber bem fundamentado também pode ser falso." (Habermas 2004, p.41)

Ora, a solução habermasiana para esta antinomia, a qual atribui o realismo conceitual à perspectiva do participante em práticas intersubjetivamente partilhadas, e vincula o atomismo-nominalismo à atitude objetivante do observador que assimila facetas da realidade não proposicionalmente previstas, incrementando o arsenal de enunciados dotados de pretensão objetiva, sustenta-se sobre a noção putnamiana de referência.

O conceito de "referência" deve explicar como o primado ontológico de um mundo compreendido em termos nominalistas pode se conciliar com o primado epistêmico do mundo da vida linguisticamente articulado. Pois o primado epistêmico não suprime o ontológico, para ainda podermos compreender num sentido realista o fato transcendental do aprendizado. (Habermas 2004, p.42)

Para Habermas, foi Putnam quem solucionou, ${ }^{20}$ em termos de referências alter-

Principia 17(3): 459-488 (2013). 
nativas a um mesmo objeto, o problema realista e falibilista de como processos de aprendizagem podem incrementar ou subverter quadros categoriais de interpretação construídos na base de práticas linguísticas compartilhadas, suscitando "progressos do conhecimento a despeito da mudança de molduras teóricas." (Habermas 2004, p.43) "Ele toma como ponto de partida o realismo interno de Putnam e sua teoria da referência direta para sustentar sua própria tese de que há um mundo objetivo independente de nós e sobre o qual podemos erguer pretensões de validade." (Bernstein 2011, p.178) Finalmente, se o conceito de referência desenvolvido por Putnam confere sensibilidade falibilista a uma consideração da relação entre linguagem e realidade pautada pelo realismo cognitivo, ${ }^{21}$ sustenta também a suposição pragmática de "um mundo de objetos que existem independentemente de toda descrição e são ligados entre si por leis." (Habermas 2004, p.43)

Recentemente, Bernstein mostrou, de forma convincente e detalhada, de que maneira o esforço teórico compartilhado por Habermas, Apel e Putnam herda a crítica à concepção de verdade como correspondência, tal como proposta pelo pragmatismo de Peirce, vinculando a ênfase sobre intuições realistas ${ }^{22}$ com uma crítica ao representacionalismo, a qual faz apelo à explicitação da dimensão intersubjetiva da validade, ou seja, às práticas intersubjetivas de justificação (Bernstein 2011, p.105-18) De maneira sistemática, Bernstein sustenta a tese de que esta combinação de propostas é entendida de forma a fazer justiça tanto ao entrelaçamento entre verdade e justificação, quanto à sua diferenciação categórica, numa tentativa de escapar tanto ao relativismo radical quanto ao contextualismo (Bernstein 2011, p.113). ${ }^{23}$

Nós podemos também compreender a motivação para Putnam, Habermas
e Apel de introduzir uma aguda distinção entre as práticas discursivas de
justificação idealmente existentes e condições ideais de justificação que ca-
pacitariam a caracterizar verdade como aceitabilidade racional sob condi-
ções epistemicamente ideais ... as condições ideais não são metas utópicas
distantes, mas antes efetivamente pragmáticas (enquanto contrafactuais) ao
nível da comunicação cotidiana e da argumentação. (Bernstein 2011, p.115)

Pode-se perceber como Habermas lança mão de diretrizes como essa em seus desenvolvimentos de maior envergadura. Para ele, o contextualismo estrito, marcado pela tese de que a verdade dos enunciados é "garantida apenas por coerência com outros enunciados já aceitos" (Habermas 2004, p.46), não se deixa coadunar com a força subversora de contextos demonstrada pelos processos de aprendizado, com o realismo cognitivo e com o sentido universalista das pretensões de verdade que transcendem contextos. Eis por que, na esteira da concepção de referência desenvolvida por Putnam, Habermas insiste num conceito discursivo de verdade, a combinação da "compreensão de referência transcendente em relação à linguagem com uma compreensão — inerente à linguagem — de verdade como assertibilidade 
ideal" (Habermas 2004, p.46). Bernstein mostrou de maneira correta como está envolvido na tese habermasiana de uma diferenciação e entrelaçamento entre verdade e justificação o ímpeto de não sucumbir ao contextualismo pragmático de Rorty e ao neo-hegelianismo pragmático de Brandom (Bernstein 2011, p.176-8) Parece-me digno de nota que Putnam tenha encontrado sua via para o "realismo interno" a partir das insuficiências percebidas naquilo que caracteriza como o "anti-realismo global" de Dummett, ${ }^{24}$ isto é, a partir de uma "semântica verificacionista" capaz de conferir maior sensibilidade à tese que identifica o ser verdadeiro ao ser verificado, compreendendo "o ser verificado num grau suficiente para garantir aceitação em condições epistêmicas suficientemente boas." (Putnam 2008, p.33) Assim, pensa Putnam, foi capaz de abandonar a ideia de uma invariável verificabilidade das proposições empíricas e o "anti-realismo forte em relação ao passado", chegando a

identificar a apreensão que um falante faz do significado de uma afirmação não com a capacidade de dizer se ela é verdadeira nessa ocasião ou se é verdadeira em circunstâncias que o falante pode efetivamente provocar, tal como o faz Dummett, mas com capacidades do falante que permitam a um falante suficientemente racional decidir se a afirmação é verdadeira em circunstâncias epistêmicas suficientemente boas. (Putnam 2008, p.34)

Ainda mais interessante, em comparação com a preocupação de Habermas a respeito da necessidade de fazer jus a nossas "intuições realistas" (Habermas 2004, p.15), é o fato de que, à crítica acerca de se sua versão da "semântica verificacionista" é ainda excessivamente idealista Putnam responde que "enquanto o grau de confirmação atribuído de fato pelos falantes a uma sentença pode ser simplesmente uma função de suas experiências sensórias ... a noção de circunstâncias epistêmicas suficientemente boas é uma noção que envolve o mundo." (Putnam 2008, p.34)

\section{Putnam e as dimensões da razão prática}

Em seu célebre livro "O Colapso da dicotomia fato/valor", de 2002, Putnam tematiza, com extrema argúcia e sofisticação argumentativa, tanto a origem da distinção entre juízos de valor e juízos de fato, quanto a influência decisiva da dicotomia ${ }^{25}$ entre fato e valor na epistemologia moderna e contemporânea, assim como também na filosofia prática (Bernstein 2011, p.155-6). Putnam indica que sua tese acerca de uma imbricação entre fato e valor tem decorrências severas naquele âmbito denominado por Aristóteles de "filosofia prática". Ao rechaçar a dicotomia, recolocando a questão da "objetividade" dos valores, Putnam refuta também a neutralidade axiológica na filosofia prática, isto é, a ideia geral, fortemente vinculada à ética deontológica de matriz kantiana, de que os valores não são passíveis de tematização racional enfática.

Principia 17(3): 459-488 (2013). 
Eis por que suas reflexões encontram um termo justamente numa controvérsia com Jürgen Habermas, reconhecido expoente contemporâneo de uma concepção deontológica da moral e o qual, segundo Putnam, "traça uma nítida distinção" entre as "normas" éticas universais e os valores não-universalizáveis e argumenta que somente as primeiras — as normas — são objetivas." (Putnam 2002b, p.15) Neste sentido, diz Putnam, "argumento ... que temos aqui uma dicotomia indefensável e que, de fato, a objetividade que Habermas postula para as normas pressupõe a objetividade de, pelo menos, alguns valores." (Putnam 2002b, p.16)

Depois de uma breve reconstrução do debate, pretendo mostrar, bem ao espírito da problematização proposta por Putnam, os limites dessa crítica e, mais à frente, os pressupostos teóricos que permitem relativizá-la a partir da posição de Habermas. Como o próprio Putnam diz na introdução de seu livro, é preciso cautela com “o fenômeno da elevação, pelos filósofos, de distinções aparentemente inofensivas a dicotomias absolutas." (Putnam 2002b, p.14) Procuro mostrar, por conseguinte, que a diferenciação proposta por Habermas não pode nem nunca foi compreendida como uma dicotomia absoluta; é pensada, ao contrário, em termos de uma continuidade favorecida pela compreensão de constituição intersubjetiva do mundo da vida que remonta, em última instância, à noção hegeliana de reconhecimento.

Apesar de reconhecer que a filosofia prática de Habermas corresponde à perspectiva de sociedades para as quais o pluralismo axiológico se tornou incontornável - um enfoque que assume que "o desacordo sobre o que a vida ética requer concretamente de nós é um fato da vida, algo que não desaparecerá" (Putnam 2002b, p.155) —, Putnam entende que o fato de nos oferecer tão somente "uma regra de como conduzir nossos inevitáveis desacordos sobre as regras de primeira-ordem que devem governar nossa conduta" (Putnam 2002b, p.155) faz com que Habermas mereça a alcunha de "filósofo moral kantiano minimalista" (Putnam 2002b, p.155). ${ }^{26}$ Com essa extrema formalização, Habermas se expõe, de acordo com Putnam, a um risco fatal: "se as normas universais kantianas, sejam elas muitas ou poucas, podem realmente esgotar o que é "objetivo" na ética ou se, por outro lado, há, algumas vezes, alguma coisa mais para os "valores" do que as contingências das histórias dos vários "mundos da vida" locais." (Putnam 2002b, p.155)

Apoiando-se fortemente na reconstrução de uma interlocução que envolve Iris Murdoch, Christine Kosgaard e Bernard Williams, Putnam defende a tese geral de que nossas máximas éticas contêm conceitos éticos espessos, isto é, contém elementos descritivos que estabelecem intrinsecamente orientações valorativas. Sendo esse o caso, como a questão da extensão desses conceitos éticos está sempre atrelada às coordenadas estabelecidas no interior de um mundo social determinado, a questão deontológica da universalização sempre possui um caráter problemático. Por outro lado, retomando a crítica de Hegel a Kant, Putnam sustenta que, do ponto de vista da ética deontológica e de sua sensibilidade exacerbada para a forma da legislação, 
todo e qualquer conteúdo permanece incontornavelmente não-universal. Eis por que Putnam conclui dizendo que "o relativismo de qualquer tipo com relação a valores não pode deixar intactas as máximas." (Putnam 2002b, p.161) Para Putnam, Habermas está simplesmente envolvido com um projeto político-filosófico de

fazer quaisquer concessões àquilo que podemos chamar de "sociologismo com relação aos valores" - tratar as disputas de valor como, de fato, meros conflitos sociais a serem resolvidos ... e não como desacordos racionais exigindo uma decisão sobre onde se encontram as melhores razões ... podemos engajar-nos na discussão (no sentido normativo da "ação comunicativa") com o objetivo de alcançar um vocabulário comum e um entendimento comum de como esse vocabulário poderia ser aplicado. Entretanto, a menos que haja uma resposta correta para essas questões, essa discussão não pode realmente ser um esforço para encontrar uma resposta para a qual há melhores razões. (Putnam 2002b, p.162-3)

Em suma, a crítica de Putnam à ética do discurso denuncia aquilo que ele entende ser sua ambiguidade fundamental (Putnam 2002b, p.172). Ao pretender ser a fonte última de toda validade que possa se estabelecer eticamente, "a fundação de toda "validade" que a ética pode possuir" (Putnam 2002b, p.172), a ética do discurso se expõe à alternativa de que suas alegações são vazias, ou não há razões para se acreditar nelas. Isso ocorre, para Putnam, porque a alegação acerca da origem da correção moral numa situação ideal de fala é, por assim dizer, "puramente "gramatical'"' (Putnam 2002b, p.172), isto é, não fornece por si só conteúdo à correção moral em um conflito concreto, de maneira que tem sempre de se apoiar no significado ético previamente dado dos elementos constituintes da situação ideal de fala; e, além disso, tem de pressupor tal conteúdo axiológico para expressar os conceitos em meio à disputa. "Precisamos de insights tanto aristotélicos quanto kantianos ... nossa habilidade, imperfeita mas indefinidamente perfectível, de reconhecer as exigências que nos são feitas pelos vários valores é, precisamente, o que dá conteúdo à ética kantiana (ou "discursiva")." (Putnam 2002b, p.172)

Apelando à noção de conceitos éticos densos, Putnam pretende sublinhar que, como tal vocabulário axiológico é condição indispensável para nossa reflexão moral, normas não podem ter conteúdo independentemente de valores. Toda pretensão de formular normas morais sem reconhecer sua constituição axiológica conduz a um formalismo vazio. Eis por que permitir a confluência de um minimalismo moral com respeito às normas com um relativismo ético com respeito de valores acaba por solapar, sustenta Putnam, a própria validade objetiva das normas.

O ponto crítico sublinhado por Putnam é de fato forte, posto que vincula, através da acusação de não-cognitivismo das orientações axiológicas e de um flerte com o naturalismo, a dicotomia entre normas e valores à derrocada da pretensão de universalidade das normas. A acusação de flerte com o naturalismo deve ter soado, 
sem dúvida, inesperada a Habermas, um autor tão historicamente engajado em impor limites ao ideário positivista. Ao apelar a essa caracterização, Putnam procura sublinhar que a exclusão dos valores do âmbito da objetividade prática tem como decorrência sua inclusão num rol de fatos a serem descritos precisa, completa e cientificamente.

\section{Linhas Gerais de um "Pragmatismo Ético"}

A referência de Putnam à crítica de Hegel a Kant (Putnam 2002b, p.109), no contexto criado por sua própria crítica à versão habermasiana da moral deontológica, encoraja-me a uma digressão com o objetivo de delinear os traços gerais de um pragmatismo ético, o qual faculta uma melhor compreensão do debate e de sua importância.

Habermas traz até seu pensamento mais recente a ideia de uma reciprocidade dos processos de socialização e de individualização como constitutiva de falantes/ agentes competentes. A compreensão pós-mentalista, alcançada por Hegel, de que o sujeito cognoscente está, enquanto espírito, desde sempre junto de seu outro, articula-se "nas reflexões contemporâneas ... sobre a individualidade das pessoas agentes e de seus contextos de ação." (Habermas 2004, p.188) Os seres humanos constroem ou formam (ausbilden) sua individualidade em formas de vida culturais, adquirindo uma específica autocompreensão como pessoas "que como eu e outro, ego e alter, entram em relações uns com os outros e, ao mesmo tempo, formam comunidades na consciência de sua absoluta diversidade." (Habermas 2004, p.199)

Para Habermas, "este caráter individual de pessoas falantes, que se comunicam umas com as outras e que agem, reflete-se, de certa maneira, também nas formas de vida culturais e práticas que ela compartilha com outras. Hegel conheceu o desafio filosófico que reside nestes fenômenos." (Habermas 2004, p.199) Eis por que Habermas atribui a Hegel uma de suas diretrizes: "todos os fenômenos históricos têm maior ou menor participação na estrutura dialética das relações de reconhecimento recíproco, nas quais pessoas são individualizadas pela socialização (Vergesellschaftung)." (Habermas 2004, p.199) Obviamente, tal percepção tem implicações prático-cognitivas decisivas para a epistemologia das ciências humanas.

A "dialética do reconhecimento" tem seu sentido na elevação das pretensões normativas ao ser-reconhecido universal (Habermas 2004, p.210) e, num significado epistêmico, na vinculação de uma orientação de vida a uma determinada perspectiva cognitiva do mundo. Na discussão do tema na "filosofia analítica", essa ideia tem sido interpretada como explicitação da dimensão intersubjetiva da validade objetiva, a demonstração da necessidade de um conceito inferencialmente articulado de conhecimento, ${ }^{27}$ como movimento imanente desencadeado pelas insuficiências e 
instabilidade de uma forma não-inferencial, pretensamente autossuficiente, de cognição (Pinkard 1996, p.46). Neste sentido, a noção de reconhecimento corresponde à mediação entre a intersubjetividade dos sujeitos e a compreensão autoconsciente e compartilhada daquilo que pode pretender ser legítimo ou "revestido de autoridade" (authoritative reason), compondo, assim, o núcleo da concepção hegeliana de espírito (Geist) enquanto "forma autoconsciente de vida", enquanto "forma de "espaço social" refletindo sobre si mesmo acerca de se é satisfatório em seus próprios termos" (Pinkard 1996, p.8-9).

Tal reconstrução da questão hegeliana sobre moralidade/eticidade em termos da relação entre intersubjetividade e objetividade facilita a percepção das linhas gerais de uma perspectiva em filosofia prática que gostaria de chamar de pragmatismo ético. Um livro recente - intitulado "Herança Hegeliana" e que conta com textos de Brandom, McDowell, Pippin e outros - procura traçar as "inspirações" hegelianas na filosofia analítica. Interessante como tais linhas resumem os pontos em torno dos quais estamos gravitando desde o início do presente esforço. Para além da "superação hegeliana do dualismo esquema-conteúdo" (Quante 2004, p.10), da "concepção social de Hegel acerca da autoconsciência" (Quante 2004, p.10) e do "anti-cientificismo de Hegel" (Quante 2004, p.11), ${ }^{28}$ destaca-se também sua contribuição para uma tematização pela filosofia analítica das questões sistemáticas da filosofia prática.

A crítica de Hegel ao formalismo e ao ceticismo ético, sua defesa de um realismo ético com respeito a práticas sociais e sua adesão a uma concepção de ética materialmente enriquecida, são características teóricas que se contrapõem a alguns desenvolvimentos na ética e na metaética contemporânea. Como para Hegel as práticas sociais são para elas fundacionais, deixamse nele encontrar traços fundamentais de um pragmatismo ético. (Quante 2004, p.10-11)

Quante chega à interessante conclusão de que Hegel apresenta vários paralelos com o modelo de pragmatismo defendido por Putnam, sobretudo no que diz respeito ao "primado do prático sobre o teórico", à "recusa da dicotomia entre normas e valores", ao "falibilismo" na filosofia prática (Quante 2004, p.287) e a uma "posição fundamentalmente anticética" (Quante 2004, p.280). Dessa leitura inovadora, Quante conclui que

a tese hegeliana acerca da superação da moralidade na eticidade é para ser interpretada não de um ponto de vista da teoria da validade ... mas da perspectiva de uma teoria da fundamentação. Com outras palavras, trata-se para Hegel não de provar que as pretensões de validade da eticidade devem predominar sobre as pretensões de validade da moralidade, mas antes de mostrar, em primeiro lugar, que toda argumentação moral tem de se apoiar sobre premissas éticas pressupostas. (Quante 2004, p.287)

Principia 17(3): 459-488 (2013). 
Diretiva para a leitura do debate entre Putnam e Habermas em torno da objetividade axiológica é o fato de que o argumento hegeliano de "superação da moralidade na eticidade" se deixa ler como uma "estratégia pragmatista de fundamentação" (Quante 2004, p.293), profundamente vinculada à "fragilidade do espírito objetivo" (Quante 2004, p.288-91), à vulnerabilidade, portanto, da tessitura intersubjetiva dos nexos do mundo da vida aos quais os sujeitos devem, em qualquer caso, sua orientação prática. Isso significa considerar

que uma eticidade vivida na práxis e que se conserva nela não necessita de nenhuma justificação por um princípio da razão prática, a qual se apoiaria em pressuposições exteriores. Tal fundamentação filosófica, caso ela se relacione às nossas convicções éticas em conjunto, assumiria um ponto de vista do qual, segundo Hegel, nós não dispomos quando argumentamos eticamente. (Quante 2004, p.296)

\section{A Posição de Habermas e Algumas Implicações}

Em sua resposta a Putnam, Habermas atribui-lhe implicitamente adesão a um ímpeto presente no pragmatismo (Quante 2011, p.287), o primado da razão prática sobre a teórica, a fortiori a ideia de que o esclarecimento epistemológico do uso científico da razão inclui a visualização de sua natureza essencialmente prática, conduz à especificação da justificação prática das orientações de valor inseridas nos enunciados de pretensão objetiva: também a busca cooperativa pela verdade é, a despeito da pretensão axiologicamente neutra dos enunciados sobre o mundo objetivo, um empreendimento estruturado normativamente. Se a investigação é presidida por orientações em termos de relevância, coerência, simplicidade, elegância e relação à previsibilidade, ela tem de ser compreendida como estruturada intrinsecamente por valores. $^{29}$ Segundo Habermas, central para a passagem empreendida por Putnam entre a discussão epistemológica e a discussão ética é a ideia de que a objetividade de enunciados empíricos se beneficia da objetividade dos valores que presidem a investigação científica e que, por conseguinte, tem de ser possível uma determinação enfática da objetividade dos valores em geral. Para Habermas, Putnam transfere o realismo epistemológico para o registro de um realismo axiológico. ${ }^{30}$

Assim, Putnam somente seria capaz de sustentar a objetividade dos valores ao preço da enfática tese de que a objetividade dos juízos de valor se estrutura sobre a verdade dos juízos empíricos. Ao assumir que sua explicação epistemológica da validade veritativa esclarece a objetividade dos juízos em geral, Putnam passa também a sustentar, pensa Habermas, um suporte ontológico para os juízos de valor. Como não se faz necessária a suposição de um mundo factual transcendente ao "reconhecimento", o aporte ontológico da verdade, Habermas aponta em Putnam a tendência para uma teoria geral da objetividade, a qual, isomórfica à verdade dos fatos, 
vincularia a objetividade prática das normas à objetividade social dos enunciados valorativos. ${ }^{31}$

Haveria assim um nivelamento do sentido da validade do juízo. Habermas deseja, por outro lado, fazer jus à ideia kantiana de uma diferença enfática entre a validade veritativa dos juízos descritivos e a validade normativa dos imperativos categóricos, diferença pela qual a objetividade dos enunciados morais perde, de acordo com os processos históricos de modernização, a conotação ontológica do direito natural (Habermas 2002b, p.92). Em suma, lançando mão de posições cognitivistas e anti-realistas com respeito às normas e valores, Habermas critica um nivelamento entre razão teórica e razão prática e certa subserviência a um realismo axiológico, comprometido metafisicamente com entidades, fatos e propriedades de valor, proveniente da equiparação entre validade empírica e valorativa. Através de sua insistência "kantiana" na diferenciação entre razão teórica e razão prática, ${ }^{32}$ Habermas se afasta, como mostra Bernstein, do pragmatismo de James, Dewey, Putnam e Rorty, embora permaneça vinculado a Pierce (Bernstein 2011, p.181).

As normas universalizáveis merecem reconhecimento porque são de interesse de todos, ou porque são igualmente boas para todos e cada um. A validade das normas se mede pelas relações antecipadas de reconhecimento recíproco em um "reino dos fins" inclusivo. As normas não se referem ao mundo objetivo como o fazem os fatos, isto é, não se ajustam às restrições às quais estamos submetidos em nosso trato com a realidade que nos frustra, um trato que é guiado pela resolução de problemas. (Habermas 2002b, p.92, grifo meu)

Habermas acusa Putnam de associar à separação entre dever e inclinação uma tendência ao naturalismo axiológico. Parecendo retomar uma ideia que foi muitas vezes utilizada por Hegel em sua crítica a Kant - Fiat iustitia pereat mundus - Putnam entende que a tendência a reduzir todas as orientações valorativas não morais a inclinações viola a própria moralidade, entendida aristotelicamente como potencial cooperativo para uma vida bem sucedida. Eis por que, pensa Habermas, é conduzido a sustentar que

os juízos de valor devem formar enunciados que podem ser verdadeiros ou falsos no sentido de um realismo concebido de maneira pragmatista, não somente no interior da exígua camada deontológica das questões de justiça, senão no sentido amplo de todo o espectro das questões relativas à vida que se considera desejável. (Habermas 2002b, p.93)

Por um lado, apoderando-se da noção de "conceitos éticos densos", 33 Putnam procura dar conta, do ponto de vista da filosofia prática, da imbricação entre fato e valor: pela utilização de um vocabulário que, ao mesmo tempo em que descreve, estabelece uma orientação axiológica, os falantes estruturam posturas e perspectivas

Principia 17(3): 459-488 (2013). 
normativas que não condenam o desejável ao degredo naturalista. Habermas não discorda em absoluto da ideia de que no vocabulário valorativo e nas regras de uso dos enunciados normativos se sedimentam elementos imprescindíveis do saber prático de uma comunidade linguística, mas contesta que tal perspectiva teórica tenha explicado aquilo que se propunha explicar, a saber: a objetividade dos valores. Lançando mão da ideia hegeliana de que os nexos axiológicos que estruturam a vida comunitária se nutrem do reconhecimento intersubjetivo, Habermas pretende, ao contrário do que lhe critica Putnam, reconstruir a objetividade dos valores em termos da tessitura intersubjetiva do mundo da vida, para além, portanto, de uma objetividade forjada apenas a partir do fato social da aceitação de padrões de valor.

Seguindo evidentes inspirações hegelianas, Habermas sustenta que aos valores corresponde certa objetividade, mas não uma objetividade que devesse ser entendida de modo realista segundo o modelo de comprovação factual do conteúdo empírico. Trata-se de uma objetividade que repousa sobre o reconhecimento intersubjetivo de padrões axiológicos para os quais podemos encontrar boas razões com referência a uma forma de vida correspondente. Portanto, seguindo Hegel, Habermas concebe a objetividade dos juízos de valor como intersubjetividade (Habermas 2002b, p.98), isto é, concebe tal objetividade com referência a determinadas comunidades. Dessa forma, Habermas logra tematizar, num só lance, não somente a similitude das pretensões de validade envolvidas em juízos empíricos e em obrigações morais, como também sua enfática diferenciação, a qual obstaculiza o nivelamento e, como gostaria Putnam, o tratamento dos nexos axiológicos sob a orientação do realismo epistemológico.
São "corretos" aqueles juízos morais que merecem reconhecimento universal, e isto significa que poderiam encontrar o assentimento de todas as pessoas afetadas dentro de um discurso racional conduzido sob condições aproxi- madamente racionais. A analogia com a pretensão de verdade consiste na exigência de aceitabilidade racional; também a verdade dos enunciados des- critivos somente pode se revelar e se comprovar em discursos racionais que sejam tão compreensivos e duradouros quanto seja possível ... Enquanto a "correção" é um conceito epistêmico e não significa outra coisa que o mere- cimento de reconhecimento universal, o sentido da verdade dos enunciados não pode acabar saturado por condições epistêmicas de confirmação, por mais exigentes que sejam: a verdade vai mais além do que a justificação idealizada. Esta diferença entre "verdade" e "correção moral" é um reflexo da distinção entre razão teórica e razão prática. (Habermas 2002b, p.99)

Frente a essa conjunção entre semelhança e diferença categórica, a validade deôntica compartilha com a objetividade dos juízos de valor a dimensão social do reconhecimento. ${ }^{34}$ Apesar do direcionamento kantiano e das críticas ao resgate de Hegel proposto pela pragmática normativa de Brandom — por razões similares àque- 
las presentes na crítica a Putnam - Habermas guia-se por noções hegelianas. Tratase, sobretudo, da ideia de que o ponto de vista da moral deontológica e da justificação mantém, com o ponto de vista axiológico da eticidade, uma relação de continuidade, relação esta que é pensada em termos de uma estruturação intersubjetiva ou comunicativa do mundo da vida, uma relação que, afinal, é pensada através do conceito hegeliano de reconhecimento. ${ }^{35}$

Putnam julga que Habermas tenha deixado de responder a principal questão levantada por ele.

Minha afirmação decisiva era que a noção de uma "situação ideal de fala" é vazia na ausência de conceitos éticos espessos. A não ser que se admita que os enunciados que contém conceitos éticos espessos tem a capacidade de ser "válidos" tout court, que são corretos e não meramente racionais dada a "concepção de bem" compartilhada por uma determinada comunidade, então a ética do discurso, como o kantismo em geral, será um formalismo vazio. (Tal como Hegel poderia tê-lo expressado, o imperativo categórico somente tem conteúdo diante do pano de fundo da eticidade.) (Putnam 2002a, p.109)

Apesar de reconhecer sua própria crítica como uma modulação do argumento hegeliano contra Kant, Putnam não parece perceber o quanto Habermas se beneficia de ressalvas hegelianas, sobretudo vinculadas às noções de reconhecimento e intersubjetividade, em seu construtivismo do ponto de vista moral. ${ }^{36}$ De fato, Habermas não pretende que a racionalidade procedimental envolvida na justificação de normas possa prescindir das orientações axiológicas sedimentadas nos jogos de linguagem constitutivos de formas de vida concretas. Na verdade, Habermas sustenta que o ponto de vista do discurso pressupõe aquelas orientações valorativas inseridas nos assim chamados conceitos éticos densos. Mas, segundo Putnam, "estas palavras são consideradas como significativas tão somente em relação a comunidades particulares, essas leis poderiam, apesar de tudo, possuir uma universalidade formal, mas seu conteúdo seria tudo menos universal. Qualquer tipo de relativismo com respeito aos termos valorativos não pode deixar de afetar a objetividade das normas." (Putnam 2002a, p.110) Putnam continua a insistir na ideia de que conceitos éticos espessos, sobretudo aqueles necessários à caracterização do ponto de vista da moral deontológica, são um pressuposto não para a validade das normas "universais" da ética do discurso, mas para sua determinação de conteúdo.

Para Habermas, por mais que tenham sido desencadeadas no interior de condições éticas e particulares próprias a uma comunidade, questões morais relativas à justiça constituem um modo específico de indagação, não redutível à reflexão de um indivíduo e de uma comunidade como um todo, mas que diz antes respeito à regulação de conflitos sob a consideração do interesse de todos. Enquanto Putnam aposta no reconhecimento dos potenciais universalistas inerentes às orientações axi-

Principia 17(3): 459-488 (2013). 
ológicas particulares, Habermas é mais sensível ao movimento autorreflexivo das formas de vida como único expediente capaz de promover uma inclusão ampliada e uma recíproca assunção de perspectivas. Enquanto para Putnam a radicalização do pluralismo ultrapassa todas as questões controversas, Habermas entende o ponto de vista moral sempre como uma limitação intrínseca do pluralismo na direção de uma universalidade axiológica dotada de uma forma de objetividade cognitiva particular.

Em paralelo à absorção hegeliana do conceito aristotélico de "segunda natureza", Habermas entende a objetividade dos valores sob a égide de um cognitivismo fraco, isto é, como reconhecimento intersubjetivo dos resultados mais bem garantidos racionalmente com respeito à concepção de bem viver na perspectiva da primeira pessoa. Entretanto, são apenas enquanto incorporadas nesta compreensão prática compartilhada que podem se formar nossas deliberações morais e, por conseguinte, as normas com pretensão de validade universal. O ponto de vista moral surge a partir de dentro das condições éticas de uma comunidade e de sua forma de vida compartilhada, provocando, na autocompreensão dos participantes, uma diferenciação em relação ao ponto de vista egocêntrico ou etnocêntrico dos discursos éticos, uma diferenciação entre questões de justiça e questões do bem viver.

A correção normativa deve ser considerada apenas do ponto de vista da justificação e aceitabilidade racional e, muito embora prescinda de uma dimensão ontológica, não é por isso absolutamente transcendente em relação ao reconhecimento dos participantes, às demandas de justificação racional contemplada desde a perspectiva ético-existencial, estabelecendo, com as orientações axiológicas compartilhadas, um alto grau de continuidade. ${ }^{37}$ Ao fim e ao cabo, Habermas condena na postura de Putnam a tendência para certa dependência em relação a valores transcendentes. Não poderia ser de fato o caso de que alguns enunciados valorativos fossem objetivos graças à mera aceitação social no âmbito de uma comunidade. A validez social não pode resumir o conteúdo normativo de enunciados embasados em discursos orientados pela inclusão de todos os possíveis participantes, sua força para transcender a partir de dentro contextos exíguos. Mas, se é assim, se a objetividade dos enunciados valorativos deriva de um reconhecimento intersubjetivo limitado contextualmente, tal limite nada mais é do que o conteúdo normativo dos enunciados morais, a ideia de que a dimensão social da validade não pode exigir uma aprovação universal. "O construtivismo moral mostra que nós, e somente nós, temos a responsabilidade de justificar normas morais universais." (Bernstein 2011, p.194)

Voltando ao "pragmatismo ético" de Hegel, a "continuidade"38 entre o discurso prático e a racionalidade comunicativa pela qual os sujeitos coordenam suas ações cotidianamente implica numa relação intrínseca entre normatividade e os processos de individualização e socialização. O ponto de vista moral e a atitude hipotética frente a normas tornadas problemáticas, a qual se sedimenta em juízos morais e em ações conformes aos mesmos, dependem de que processos de socialização e indivi- 
dualização, processos intersubjetivos que tecem a rede de relações da eticidade de uma forma de vida, tenham podido torná-los aptos a se deslocar do estofo tradicional que responde pelas obviedades normativas. ${ }^{39}$ Mas, para além disso, de um ponto de vista antropológico, a moral pode ser compreendida como um mecanismo de proteção à vulnerabilidade estrutural das formas de vida socioculturais, isto é, à característica incontornável da espécie humana de somente ser capaz de proceder à individualização pela via da socialização. As formas de vida socioculturais se caracterizam, portanto, pelo fato de que os processos comunicativos que subjazem à intersubjetividade da interação, constroem e reproduzem originariamente a identidade do indivíduo e da coletividade sociocultural. A moral se dirige, em geral, a aplacar esta vulnerabilidade na forma da salvaguarda tanto da integridade individual, quanto do "tecido vital das relações de reconhecimento recíproco nas quais unicamente as pessoas podem estabilizar sua frágil identidade." (Habermas 1986, p.24) A filosofia moral deve se voltar axiologicamente tanto à intangibilidade dos indivíduos pela exigência de respeito à dignidade de cada um, quanto à proteção da tessitura intersubjetiva das relações comunitárias.

\section{Referências}

Bernstein, R. 2010. The Pragmatic Turn. Cambridge: Polity Press.

Brandom, R. 2002. Tales of the Mighty Dead: Historical Essays in the Metaphysics of Intentionality. Cambridge: Harvard University Press.

Encabo, J. V.; Martin, F. J. G. 2008. Pragmatismo, Objetividad Normativa y Pluralismo. El Debate sobre Normas y Valores entre H. Putnam y J. Habermas. In: J. Habermas; H. Putnam. Normas y Valores. Madrid: Editorial Trotta, p.9-46.

Habermas, J. 1989. Consciência Moral e Agir Comunicativo. Rio de Janeiro: Tempo Brasileiro.

—. 1991. Escritos sobre moralidad y eticidad. Barcelona: Padiós, I.C.E-U.A.B.

- 2002a. Racionalidade e Comunicação. Lisboa: Edições 70.

—. 2002b. Werte und Normen. Ein Kommentar zu Hilary Putnams Kantischen Pragmatismus. In: M.-L. Raters; M. Willaschek. Hilary Putnam und die Tradition des Pragmatismus. Frankfurt am Main: Suhrkamp, p.280-305.

- 2004. Verdade e Justificação: ensaios filosóficos. São Paulo: Loyola.

McDowell, J. 1996. Mind and World. Cambridge: Harvard University Press.

Nuzzo, A. 2010. Hegel and the Analytic Tradition. New York: Continuum.

Oliveira, M. A. 2001. A reviravolta lingüístico-pragmática na filosofia contemporânea. São Paulo: Vozes.

Pinkard, T. 1996. Hegelt's Phenomenology. The Sociality of Reason. Cambridge: Cambridge University Press.

Putnam, H. 1987. The Many Faces of Realism. Open Court, La Salle, I11.

-1990. Realism with a Human Face. Cambridge: Harvard University Press.

. 2001. Werte und Normen. L. Wingert; K. G. Die Öffentlichkeit der Vernunft und die Vernunft der Öffentlichkeit. Festschrift für Jürgen Habermas. Frankfurt am Main: Suhrkamp,

Principia 17(3): 459-488 (2013). 
p.280-313.

- 2002a. Antwort auf Jürgen Habermas. In: M.-L. Raters; M. Willaschek. Hilary Putnam und die Tradition des Pragmatismus. Frankfurt am Main: Suhrkamp, p.306-321.

- 2002b. Colapso da Verdade e outros Ensaios. Aparecida (SP): Editora Idéias e Letras.

- 2004. Ethics without Ontology. Cambridge: Harvard University Press.

- 2008. Corda Tripla: Mente, Corpo e Mundo. Aparecida (SP): Editora Idéias e Letras. Quante, M. 2004. Hegels Erbe. Frankfurt am Main: Suhrkamp.

_. 2011. Die Wirklichkeit des Geistes: Studien zu Hegel. Frankfurt am Main: Suhrkamp. Rajchman, J. 1985. Post-Analytic Philosophy. New York: Columbia University Press.

Redding, P. 2007. Analytic Philosophy and the Return of Hegelian Thought. New York: Cambridge University Press.

Rockmore, T. 2005. Hegel, Idealism, and Analytic Philosophy. New York: Yale University Press. Sellars, W. 1997. Empiricism and the Philosophy of Mind. Cambridge: Harvard University Press.

Wittgenstein, L. 1984. Werkausgabe in 8 Bänden. Frankfurt: Suhrkamp.

ERICK LIMA

Departamento de Filosofia

Universidade de Brasília.

Programa de Pós-graduação em Filosofia

Universidade de Brasília (PPGFIL-UnB).

callima_er@hotmail.com

Resumo. Pretendo explicitar algumas implicações epistemológicas do debate entre Putnam e Habermas acerca da objetividade dos valores. Inicialmente, gostaria de construir, recorrendo a reflexões em filosofia da linguagem e no neopragmatismo, o horizonte teórico no qual se possa entender de maneira menos unilateral a relação entre naturalismo e a normatividade das "formas de vida" (1). Tais considerações devem funcionar como uma explanação do contexto filosófico em que se desenvolve o debate Habermas/Putnam. Em seguida, gostaria de resumir a posição de Putnam (2). Em terceiro lugar, a partir daquilo que parece ser a direção argumentativa compartilhada, pretendo evidenciar a pertinência do debate para os atuais questionamentos em filosofia prática, delineando os contornos do "pragmatismo ético" (3). Finalmente, procuro mostrar que Habermas escapa à crítica de Putnam aderindo implicitamente à tese da vinculação da moral deontológica a uma orientação axiológica em termos de vulnerabilidade (4).

Palavras-chave: Pragmatismo; realismo; naturalismo; normatividade; Habermas; Putnam.

\section{Notas}

${ }^{1} \mathrm{O}$ debate em torno independência do ponto de vista moral em relação a quadros valorativos tem ressonâncias no pensamento político. "A moral do respeito equitativo e da responsabilidade solidária para todos e qualquer um já não pode se justificar desde a perspectiva ética de uma comunidade particular, preocupada acerca de seu bem estar, da mesma maneira

Principia 17(3): 459-488 (2013). 
que tampouco podem se justificar, a partir dessa perspectiva, os direitos humanos ou o estado constitucional democrático. Putnam quer conciliar ambas as coisas sob o denominador comum de um realismo cognitivo." (Habermas 2002b, p.105) "A refutação da diferenciação entre validade veritativa e validade deôntica ameaça precisamente a concepção universalista da moral que Putnam de forma alguma gostaria de sacrificar." (Habermas 2002b, p.101) "Os princípios do universalismo igualitário, dos direitos humanos e da democracia, os fundamentos normativos do pluralismo sensível às diferenças são realmente conciliáveis com uma ética pragmatista do valor? " (Habermas 2002b, p.103)

${ }^{2}$ Habermas vê nessa circunstância a proximidade, inspiradora para a epistemologia contemporânea, entre Wittgenstein e Heidegger, à diferença de que aquele chega a semelhante primazia do a priori do sentido de uma maneira não tão mistificadora. De fato, pensa Habermas, tal combinação marca, em termos da confluência das motivações oriundas do historicismo superior dos jogos de linguagem e das aberturas do mundo epocais, direcionamento perceptíveis na teoria pós-empirista da ciência (Kuhn), na filosofia neopragmática da linguagem (Rorty) e na crítica pós-estruturalista da razão.

3 "A exigência pragmática que nos leva a adotar a perspectiva do outro — junto com a suposição realista de um mundo objetivo e com o requisito da consistência lógica - forma a base de um espaço comum sobre o qual mesmo os interlocutores que estão culturalmente muito distanciados entre si podem se corrigir mutuamente e desenvolver uma linguagem comum. É certo que não há um uso da razão que esteja livre do contexto e que não há padrões de racionalidade que não tenham que ser interpretados em contextos locais. Mas, no processo da própria crítica, a razão se defende performativamente contra todas as determinações locais ... A razão não é um processo que flui livremente, senão que na realização da razão que se encontra situada em cada caso concreto está inscrita a tendência de transcender a partir de dentro todos os contextos, ainda quando seja somente para reaparecer de imediato em contextos mais amplos e em outras encarnações." (Habermas 2002b, p.88-9)

${ }^{4}$ Nesta compreensão das exigências modernas do que se deva chamar "experiência", reside o que Brandom sustenta ser o compromisso filosófico, herdado de Kant por Hegel, com o caráter normativo dos conceitos, "lógico-estruturais" e "empíricos", o que Brandom entende, na esteira de Wittgenstein, como o que perfaz a exigência filosófica de expor as condições de possibilidade da determinidade de nossos compromissos, responsabilidades e obrigações (Brandom 2002, p.212 e 214). O pragmatismo semântico residiria na radicalização desta compreensão do conteúdo conceitual em termos das operações envolvidas na aplicação do conceito (Brandom 2002, p.210).

5 "A linguagem nos castiga, por assim dizer, privando-nos de sua dimensão semântica tão logo nós a observamos a partir de fora e com uma atitude objetivadora. E isso continua valendo para as operações e as formas de expressão da mente humana em geral. Dado que estão estruturadas normativamente, somente podem ser descritas e tornadas explícitas em um vocabulário normativo: a razão não pode ser naturalizada." (Habermas 2002b, p.86)

6 "O saber intuitivo sobre como seguir uma regra e sobre o que significa infringi-la possui por natureza um caráter normativo; este se subtrai a uma observação que se limita a regularidades empíricas. De resto, visto que todas as estruturas simbólicas do mundo da vida se diferenciam a partir do medium da linguagem, a análise do uso linguístico orientado pelo entendimento mútuo, feita da perspectiva dos participantes, fornece a chave para a rede de práticas do mundo da vida como um todo." (Habermas 2004, p.24-5)

Principia 17(3): 459-488 (2013). 
${ }^{7}$ A noção hegeliana de reconhecimento (Anerkennung) é uma das mais ricas e instigantes nos esforços atuais em teoria das ciências humanas. Paralelamente à relação entre o reconhecimento e a noção de mundo da vida estruturado linguisticamente, que responde pelo engate da racionalidade procedimental nos processos de socialização e individualização, essa ideia tem atuado também "filosofia analítica", apesar de seus primórdios anti-hegelianos (Habermas 2004), (Rajchman 1985) e (Rockmore 2005). Rorty sustentou inclusive um deslocamento, na "filosofia analítica", do registro kantiano para o hegeliano, cujo principal fomentador seria Brandom (Sellars 1997). Os continuadores de Sellars tomaram a mediação intersubjetiva da validade como ainda mais central (Redding 2007, capítulo 6), fortalecendo uma tendência que tem arrebatado atuais correntes analíticas, herdeiras, em geral, do último Wittgenstein - aquelas que resultam de um desenvolvimento da "virada linguística" num sentido "pragmático" (Oliveira 2001), articulando mais intimamente as dimensões representacional e comunicacional da linguagem (Bernstein 2010, p.106). A mediação intersubjetiva da validade, enquanto articulação inferencial e linguística da cognição, holismo semântico e teoria inferencial do conteúdo, tem se tornado, portanto, característica de uma proposta analítica refratária ao construtivismo linguístico, ao mentalismo e ao representacionalismo atomista (Redding 2007, capítulos 1 e 2), (Nuzzo 2010, p.6), (McDowell 2009, partes I e II) e (Brandom 2002, capítulos 6 e 7).

${ }^{8}$ A tese do significado como uso (Wittgenstein 1984, 1, p.262), a qual articula os problemas do significado e da compreensão, sustenta uma concepção pragmática de linguagem para a qual a comunicação e apreensão do sentido estão incontornavelmente vinculadas ao aferimento de performances apropriadas a regras, aferimento cujo critério é a própria utilização da linguagem por uma comunidade linguística. Eis por que a discussão da compreensão do sentido e do significado como contrapartida de performances apropriadas serve à sustentação das importantes posições segundo as quais compreender sentenças ou palavras significa compreender uma linguagem (Wittgenstein 1984, 1, p.344), isto é, engajar-se numa prática comunitária (Wittgenstein 1984, 1, p.345) regida por regularidades (Wittgenstein 1984, 1, p.345) que sedimentam a normatividade de uma forma de vida (Wittgenstein 1984, 1, p.356).

9 "Assim, é ainda mais paradoxal a tarefa de explicar empiricamente a gênese dessas condições de possibilidade intersubjetivas da experiência em geral. Um explanans, que explica a gênese das condições transcendentais, já deveria, ele mesmo, obedecer às condições invocadas no explanandum." (Habermas 2004, p.29) Em sua principal crítica ao "naturalismo estrito", Habermas faz notar que a própria pretensão de distanciamento cientificista em relação ao saber intuitivo já o faz solapar em seus fundamentos; pois, de um lado, os falantes/agentes competentes, envolvidos em práticas cotidianas, não podem se eximir de um agir atinente a normas e regras, não podendo se reconhecer numa descrição excessivamente objetivante. Mas, por outro lado, cria-se o hiato entre as práticas em cujo envolvimento os falantes/agentes se sabem conscientes e a descrição puramente causal de seu comportamento erguida pela ciência (Habermas 2004, p.32).

10 "Uma estratégia de explicação "estritamente" naturalista tem a intenção de substituir a análise conceitual de práticas do mundo da vida por uma explicação científica - por exemplo, neurológica ou biogenética — das operações do cérebro humano." (Habermas 2004, p.36)

${ }^{11}$ A propósito, Habermas lembra que "o vocabulário do aprendizado ... não pode, por sua

Principia 17(3): 459-488 (2013). 
vez, ser simplesmente reinterpretado na conceitualidade neodarwinista ... Pois a concepção da evolução natural como um processo análogo ao aprendizado assegura um conteúdo cognitivo às próprias estruturas que têm uma gênese natural e possibilitam nossos processos de aprendizado." (Habermas 2004, p.37)

${ }^{12}$ Recordo aqui a enunciação proposta por Habermas para a "questão epistemológica do realismo": "como conciliar a suposição de um mundo independente de nossas descrições, idêntico para todos os observadores, com a descoberta pela filosofia da linguagem de que nos é negado um acesso direto, não mediado pela linguagem, à realidade nua?" (Habermas 2004, p.8)

${ }^{13}$ Desenvolvimentos paralelos ajudam a ver a envergadura de uma reação fundada no pragmatismo às insuficiências teóricas da filosofia moderna (Berstein 2011, p.95-105). Poderíamos dizer que Brandom e McDowell desenvolvem duas implicações possíveis da "assimilação", empreendida por Wilfrid Sellars (Redding 2007, cap. 1 e 2), de Hegel para filosofia analítica. Sellars pretende, em suma, um resgate de Hegel com o intuito de resolver as aporias da filosofia analítica com respeito ao que chama, recuperando Russell, de "mito do dado" (Redding 2007, p.29) (Sellars 1997, p.13ss). De fato, Hegel está amplamente movido pela rejeição do resíduo de um dado não conceitual, proveniente inexoravelmente de "fora" e que caracteriza o subjetivismo ou representacionalismo da epistemologia moderna, resultados que podem ser descritos, de maneira geral, como decorrentes de uma diferença absoluta de forma e conteúdo. McDowell (Nuzzo 2010, p.96 e 158) corresponde ao desideratum de uma reinterpretação do "mito do perceptivamente dado" (Redding 2007, p.56). Inserindo-se num ensejo criado pelo próprio Hume, ao mencionar o exemplo do "matiz de azul", McDowell promove uma discussão em torno do conteúdo não-conceitual da experiência de percepção de cores, discussão que se processa no sentido de repensar a diferenciação categórica entre conceito e intuição fora do representacionalismo atomista (Brandom 1994, p.93), e que conduziu, inclusive, a uma visualização da noção hegeliana de negação determinada (Redding 2007, p.22). Com efeito, os seguidores de Sellars apelam a Hegel, em primeiro lugar, em favor de um "contextualismo cognitivo" (Redding 2007, p.18). Putnam apresenta considerável proximidade a este encaminhamento. "McDowell ... defende convincentemente que essa imagem, seja na versão clássica ou na materialista moderna, é desastrosa para quase todas as partes da metafísica e da epistemologia. Do ponto de vista de McDowell, o pressupostochave responsável por esse desastre é a ideia de que tem de haver uma interface entre nossas capacidades cognitivas e o mundo exterior ... a ideia de que nossas capacidades cognitivas não conseguem chegar aos próprios objetos" (Putnam 2008, p.24).

${ }^{14}$ Aqui convém uma referência a filósofos como Wittgenstein e Austin, mais enfaticamente ligados à ideia do caráter normativo das "regras gramaticais" para o significado, mas também à forma muito importante como os mais ilustres expoentes do pragmatismo (James, Dewey, Pierce) investigam o problema da objetividade. Por exemplo, "Pierce não duvida que há coisas reais que são independentes de nosso pensamento e constrange nossas opiniões. Mas ele problematiza a tese de que nós possamos ter um conhecimento direto, imediato, intuitivo do que é real. Todo conhecimento como este envolve ou pressupõe processos inferenciais." (Bernstein 2011, p.111)

${ }^{15}$ Refiro-me aqui principalmente àquela forma mais ampla desse desenvolvimento (Wittgenstein 2006, 1, p.356-80) Para a apropriação crítica proposta por Putnam, ver sua terceira conferência (Putnam 2008, p.65 e seguintes).

Principia 17(3): 459-488 (2013). 
${ }^{16}$ Há que se ver aqui, sem dúvida, os traços inconfundíveis do compromisso de Putnam com estratégias provenientes do pragmatismo norte-americano, sobretudo a forma como o neopragmatismo absorve a discussão em torno da objetividade (Bernstein 2011, p.105-24).

17 Sugiro aqui a origem dessa ideia de Putnam nas reflexões do pragmatismo norte-americano sobre a noção de experiência (Bernstein 2011, p.88-96), bem como na inaudita influência, em seu viés dinâmico, da noção hegeliana de experiência na formulação da temática nessa tradição (Bernstein 2011, p.105-24), em especial a forma como a Dewey absorve, no sentido de uma "naturalização darwiniana" (Bernstein 2011, p.144-5).

${ }^{18}$ Para uma apreciação de desenvolvimentos paralelos sobre essa ideia de responsabilidade linguisticamente articulada das pretensões de validade: "A ideia mestra, que anima e estrutura a lógica e a metafísica de Hegel, é sua maneira de desenvolver, de acordo com o modelo de autoridade recíproca e responsabilidade cujo paradigma é o reconhecimento recíproco, o insight de Kant-Rousseau acerca do tipo fundamental de normatividade baseada na autonomia." (Brandom 2002, p.234) Daí porque se torna instigante uma discussão acerca da articulação intersubjetiva da noção de responsabilidade em termos de "reconhecimento recíproco", enquanto normatividade conceitual envolvida em pretensões de objetividade. "Para Hegel, assim como para Kant, todas as normas são normas conceituais: falar de normas e falar de conceitos são duas maneiras de caracterizar um fenômeno comum fundamental. A primeira coisa a perceber é que Hegel entende conceitos, o conteúdo das normas, como essencialmente articulado inferencialmente." (Brandom 2002, p.223)

${ }^{19}$ Recordo a formulação paradigmática do "holismo semântico" — a discussão de Wittgenstein sobre uma passagem do Teeteto de Platão na qual, a partir da primazia da descrição sobre a denominação, é possível uma crítica à noção de individuals em Russell (Wittgenstein 1984, 1, p.263-4), de resto reconhecida pelo próprio Wittgenstein como uma radicalização do princípio fregeano do contexto (Wittgenstein 1984, 1, p.267). Brandom entende, em geral, o holismo como sendo uma posição epistemológica que rejeita o atomismo semântico por sustentar que a imediatidade pressupõe determinidade de conteúdo, articulação do conteúdo determinado por relações de incompatibilidade material, o que significa, por sua vez, a ideia de que a "imediatidade somente pode ser feita inteligível frente ao pano de fundo de relações mediadoras de exclusão." (Brandom 2002, p.182-3) No Tractatus LogicoPhilosophicus, Wittgenstein menciona que "apenas a proposição tem sentido (Sinn); apenas no contexto de proposição um nome tem significado (Bedeutung)." (Wittgenstein 1984, 1, p.20) Uma enunciação típica da maneira pela qual o Wittgenstein dos anos trinta começa a radicalizar este princípio no sentido de um holismo semântico aparece no Livro Azul: "o signo (a sentença) obtém seu significado a partir de um sistema de signos, a partir da linguagem à qual ele pertence. Em suma: compreender uma sentença significa compreender uma linguagem. Enquanto parte de um sistema de linguagem, pode-se dizer, uma sentença tem vida." (Wittgenstein 1984, 5, p.21) Finalmente, no "holismo semântico" vê a radicalização de toda a crítica do modelo mentalista e veicular de linguagem, enquanto mera verbalização do receptáculo mental de cognições, crítica que, de um modo ou de outro, desemboca na defesa que Wittgenstein faz do caráter público da linguagem (Wittgenstein 1984, 1, p.356-80), com o que reencontramos as intenções da epistemologia de Putnam (Putnam 2008, p.65 e seguintes).

20 "Putnam desenvolve na linha do "realismo pragmático" uma solução que se encaixa perfeitamente no contexto de minhas reflexões." (Habermas 2004, p.43)

Principia 17(3): 459-488 (2013). 
21 "A teoria da referência de Putnam explica como, na referência constante, podemos melhorar a determinação conceitual de um objeto ... . Nisso, o saber linguístico, que nos faz ver o mundo de determinada forma, torna-se, por sua vez, função do saber ampliado sobre o mundo. Isso só é possível se somos capazes de nos referir ao mesmo objeto sob diferentes descrições teóricas. Entretanto, a invariância da referência de enunciados concorrentes, invariância que transcende as diferentes teorias, ainda não explica qual desses enunciados é verdadeiro. A verdade dos enunciados descritivos só pode ser fundamentada à luz de outros enunciados, e a de opiniões empíricas só com o auxílio de outras opiniões." (Habermas 2004, p.45)

22 Bernstein faz uma contundente crítica à maneira como Habermas procura recentemente fazer jus a estas "intuições realistas" em sua pragmática formal (Bernstein 2011, p.175 e seguintes)

${ }^{23}$ Tanto para os autores em pauta quanto para o intérprete que acionei, as posições epistemológicas assumidas por Rorty são as mais representativas dessa tendência (Bernstein 2011, p.177 e seguintes).

${ }^{24}$ Segundo Habermas, Dummett segue, apesar de tudo, as pegadas de um "kantismo linguístico" (Habermas 2004, p.14), de maneira que o "construtivismo anti-realista" propugnado por ele, devido ao fato de que se nutre dos tópicos suscitados por uma crítica ao realismo metafísico, permanece, ao menos segundo o espírito, compatível com o "realismo interno" desenvolvido por Putnam.

${ }^{25}$ Ao conferir às dicotomias filosóficas uma utilidade vinculada a certos propósitos, como mostra Bernstein, Putnam segue Dewey (Bernstein 2011, p.160).

26 "Enquanto o tratamento das normas é "kantiano", no sentido de que o poder obrigatório das normas ... da "ética discursiva", é identificado ao poder obrigatório do próprio pensamento e da comunicação racionais, os "valores", em contraste, são tratados naturalisticamente. Eles são vistos como produtos sociais contingentes, que variam conforme variam os diferentes "mundos da vida". As restrições da moralidade entram em conexão com os valores em, digamos, um "metanível" ... Somente os valores que podem sobreviver a essa defesa são legítimos." (Putnam 2002b, p.151)

${ }^{27}$ Pinkard entende que a autoconsciência, equipada com a capacidade de gerar um ceticismo sobre suas próprias posições em seus próprios termos, torna-se, "ao menos minimamente [,] a assunção de uma posição no 'espaço de social' " (Pinkard 1996, p.7), isto é, o criticismo para avaliação de motivos elencados nas práticas sociais de fornecer razões (Reason-giving). Sendo assim, segundo Pinkard, "o fornecimento de razões ... é ele mesmo uma prática social que atua no âmbito de uma forma determinada de "espaço social", permitindo alguns tipos de inferência e falhando em permitir outras" (idem, p.8). Eis por que, sendo uma consideração reflexiva e autoconsciente dos padrões e normas que reivindicam legitimidade, "todas estas formas de autoconsciência tem uma estrutura mediada (isto é, inferencial)." (Ibidem) Do ponto de vista histórico-filosófico, a tese de uma alegada "socialidade da razão", a qual pretende que esteja em curso em Hegel "uma teoria normativa do agir racional de indivíduos ocupando posições no interior de um "espaço social" compartilhado e governado por regras" (Redding 2007, p.14), representa uma ainda mais estreita relação entre o idealismo alemão (Kant, Fichte e Hegel) e a "pragmática linguística" surgida com o último Wittgenstein.

${ }^{28}$ Segundo esse traço anti-cientificista, " a normatividade inerente às nossas práticas de conhecimento e ação é irredutível, e a relação entre natureza e espírito, de causalidade

Principia 17(3): 459-488 (2013). 
e normatividade, deixa-se descrever de forma apropriada somente desde o interior dessas práticas." (Quante 2004, p.13)

${ }^{29}$ Bernstein faz uma boa discussão dos "valores cognitivos" em Putnam, estabelecendo uma conexão com o pragmatismo e o neopragmatismo (Bernstein 2011, p.157-8 ).

${ }^{30}$ É possível uma visão consideravelmente diferente daquela de Habermas acerca da "objetividade moral" em Putnam. Por um lado, mais sensível para a defesa de uma noção menos metafísica e estática da "objetividade ética": "objetividade não é um dado metafísico ou epistemológico. É antes uma contínua e conflituosa persecução que tem de ser constantemente repensada." (Bernstein 2011, p.167) Eis por que qualifica seu esforço por uma "justificação epistemológica da democracia" como versão de um "círculo hermenêutico": "ele está defendendo que nós devemos cultivar e instituir as instituições práticas - práticas que ele associa à democracia deliberativa - as quais vão permitir objetividade e argumentação razoável no enfrentamento de situações morais complexas." (Bernstein 2011, p.164). Por outro lado, o alto grau de abstração nas suas discussões em torno de formas não-metafísicas de se pensar a objetividade moral fica aquém do potencial do pragmatismo para a revitalização das questões aristotélicas (Bernstein 2011, p.166-7).

${ }^{31}$ Habermas anteriormente defendia a noção de verdade com base na analogia, fundada na assertibilidade ou justificabilidade de pretensões de validade, com a correção moral. Atualmente, para além do elemento epistêmico da justificação, deseja defender, como meio de fugir ao idealismo e ao contextualismo linguístico, uma noção de verdade que envolve o atrito com um mundo revolto, o momento ontológico da referência (Bernstein 2011, p.179). Bernstein faz uma severa crítica desta aproximação habermasiana aos temas do realismo cognitivo (Bernstein 2011, p.186-92). De acordo com Habermas, a verdade é uma noção de dupla face porque se encontra na interação do teórico com o prático, de maneira que seu "pragmatismo kantiano" combina construtivismo moral com realismo epistemológico.

${ }^{32}$ Para Bernstein, trata-se, com a diferenciação enfática entre razão teórica e razão prática, verdade e justificação, também de um motivo programático: "por que Habermas tem "horror" ao realismo moral? Ele crê que, movendo-nos nessa direção, obliterando ou mitigando a distinção entre verdade e correção moral, seria solapada sua teoria da ação comunicativa (com seus três tipos de pretensões de validade) e sua teoria discursiva da ética." (Bernstein 2011, p.193)

${ }^{33}$ Bernstein faz uma boa discussão sobre a crítica à neutralidade axiológica em Putnam (Bernstein 2011, p.159-67). Em particular, mostra sua relação com tendências contemporâneas à rejeição de uma dicotomia entre os elementos descritivos e prescritivos constitutivos de conceitos éticos espessos.

34 "Juízos morais corretos não devem sua validade universal à sua certificação pelo mundo objetivo, como ocorre com os juízos empíricos verdadeiros, mas antes a um reconhecimento racionalmente motivado que, sem dúvida, deve poder se encontrar não somente "entre nós", senão no universo discursivo de todos os sujeitos capazes de fala e ação. De acordo com o sentido construtivo da validade deôntica, todo o mundo está obrigado a produzir o referido reino inclusivo de relações interpessoais legitimamente reguladas." (Habermas 2002b, p.100)

35 "A validade deôntica das normas obrigatórias se compreende no sentido de que merecem reconhecimento universal. Esta diferenciação da dimensão de validade não significa um $d u$ alismo da validade. Pois a coação suave à assunção recíproca e inclusiva de perspectivas está

Principia 17(3): 459-488 (2013). 
inscrita no pressupostos pragmáticos da prática da argumentação, da qual depende a justificação de todas as crenças, sejam estas de tipo empírico, matemático, valorativo ou moral.” (Habermas 2002b, p.104-5)

${ }^{36}$ Faz-se necessário realçar que Habermas simplesmente não faz uso da noção de "situação ideal de fala" em sua contra-argumentação.

${ }^{37}$ Distancio-me de outras leituras críticas de Habermas, tais como as oferecidas por Rorty, Putnam, Brandom e Bernstein, apesar de que me beneficio claramente de uma indicação proposta por este último: "conduz a erro falar de "visão ética de mundo" como algo particular e "do ponto de vista moral" como universal, e contrastar o "ponto de vista moral" com "uma ética particularista do bem viver". Aqui se gostaria que Habermas fosse mais pragmatista, reconhecendo que nossos valores e normas formam um contínuo em dinâmica alteração, tal que uns são mais particulares e outros, mais universais. Além do mais, precisamos reconhecer o quanto as pretensões morais são intermináveis e abertas. Não é apenas que existem processos morais de aprendizado sobre aquilo que conta como normas morais universais ... no curso da história, consequências não antecipadas e transformações estruturais exigem reconsideração radical do próprio sentido de moralidade, responsabilidade e justiça." (Bernstein 2011, p.196)

${ }^{38}$ Num tom que instiga à reconexão entre Hegel e o pragmatismo, "quando nós nos confrontamos com novos problemas, temos que esclarecer e defender normas morais. Nós não justificamos discursivamente normas morais num primeiro momento e, depois, nós as aplicamos aos contextos. Há uma relação dialética mais dinâmica entre as escolhas práticas que nos defrontam, o esclarecimento do significado preciso das normas que nos orientam e procurar justificá-las. " (Bernstein 2011, p.198). É preciso "não nos mover de volta a Kant, mas avançar até um pragmatismo a um pragmatismo mais dinâmico e flexível no espírito de Dewey e Mead ... afirmando a continuidade entre razão teórica e prática." (Bernstein 2011, p.199)

${ }^{39}$ As ideias morais "têm que ser transformadas, como diz Hegel, em debates concretos da vida cotidiana. E assim é em realidade: toda moral universalista depende da sustentação e do apoio que lhe ofereçam as formas de vida ... Uma moral universalista necessita também de certa concordância com instituições sociais e políticas em que já estejam encarnadas ideias jurídicas e morais de tipo pós-convencional." (Habermas 1986, p.23)

Principia 17(3): 459-488 (2013). 